\title{
Syngas Performance of Biomass Gasification Using Oil Palm Fronds
}

\author{
Nurul 'Ain Hashim¹, Norzanah Rosmin² $2^{*}$ Aede Hatib Musta'amal', Ir Baharruddin Ishak ${ }^{4}$ and J. P. \\ Barton $^{5}$ \\ ${ }^{1,2 *}$ Centre of Electrical Energy System (CEES), POWER Department, Faculty of Electrical Engineering, \\ Universiti Teknologi Malaysia, Johor Bahru, Malaysia \\ ${ }^{3}$ Faculty of Education, Universiti Teknologi Malaysia, Johor Bahru, Malaysia \\ ${ }^{4}$ Tenaga Nasional Berhad (TNB), Protection Unit of Distribution Division, Johor Bahru, Malaysia \\ ${ }^{5}$ Centre of Renewable Energy System Technology (CREST), Loughborough University, Loughborough, Leicester, \\ England, United Kingdom \\ Email: norzanah@fke.utm.my
}

\begin{abstract}
This paper presents the syngas performance of oil palm fronds (OPF) using a downdraft gasification method. So far, no biogas-OPF based power plant project has been developed in Malaysia even though the production of OPF is enormous. Initially, the empirical formula of OPF is determined before the gasification system can be modeled. The model of the gasification system in a downdraft gasifier is based on four zones; the drying zone, the pyrolysis zone, the oxidation zone and the reduction zone. The main advantage of the proposed method in this work is that the chemical reactions that occur in each zone are balanced using "kilogram" terms, thus eliminating the typical "mass" equations. Using "kilogram" terms overcomes the ambiguous process of chemical reaction during mole separation in each sub-model. In this study, the composition, calorific value (CV) and energy of syngas produced from OPF downdraft gasification are analyzed using Matlab/Simulink software. The model also takes into consideration the OPF moisture content as well as air fuel ratio. It is found that the CV of syngas reduced from $8.5 \mathrm{MJ} / \mathrm{m}^{3}$ to $6.387 \mathrm{MJ} / \mathrm{m}^{3}$ and the energy reduced from $2.224 \mathrm{kWh} / \mathrm{m}^{3}$ to $1.774 \mathrm{kWh} / \mathrm{m}^{3}$ as the moisture content increased from $5 \%$ to $20 \%$. The $\mathrm{CV}$ also reduced from $8.132 \mathrm{MJ} / \mathrm{m}^{3}$ to $4.137 \mathrm{MJ} / \mathrm{m}^{3}$ and the energy reduced from $2.259 \mathrm{kWh} / \mathrm{m}^{3}$ to 1.149 $\mathrm{kWh} / \mathrm{m}^{3}$ when air fuel ratio increased from 0.26 to 0.6 .
\end{abstract}

Keywords: Downdraft, gasification, oil palm fronds, syngas, Simulink.

\section{Introduction}

Oil palm biomass is the second largest source of biomass energy in Malaysia, where its plantation area covers about 4.6 million hectares [1]. 10 percent of the oil palm biomass is processed into finished products such as palm kernel oil and palm oil while the remaining 90 percent is waste. This waste includes empty fruit bunch (EFB), palm oil mill effluent (POME), kernel shell and oil palm fronds (OPF) [2]. Oil palm biomass has the potential to produce energy, which could replace some fossil fuel and reduce negative impacts on the environment, especially in terms of carbon emissions. As of 2014, there are eight oil palm waste-based power plants in Malaysia which have generated and have sold their power [3]. Six of these plants use EFB and the remaining two plants use POME as the biomass material. There is still no power plant project based on OPF that has been developed in Malaysia even though the production of OPF is enormous.

Studies on OPF have been conducted to investigate the properties of this biomass, which include ash content and energy content. The ash content of a biomass resource indicates the amount of noncombustible material from the biomass itself. High amount of ash content can cause fouling or slagging in the gasifier. This results in lower gasifier performance due to blockage in the bed of the gasifier. A study by Atnaw et al. [4] described the ash content of different types of biomass which are OPF, straw, sugar cane, cotton stalk, hay, rice husk and pine. Pine has the highest percentage of ash content with about 50 percent. The remaining types of biomass have ash content percentages between 5 and 20 percent. Amongst all the biomasses, OPF has the lowest ash content percentage with approximately 6 
percent. In terms of energy content, the same study by Atnaw et al. [4] compared the energy content of coal, OPF, switch grass, cereal straw, corn stalk, vine shoot and wheat straw. The fuel with the highest energy content is coal with approximately $26 \mathrm{MJ} / \mathrm{kg}$. Wheat straw has the lowest energy content at 13 $\mathrm{MJ} / \mathrm{kg}$ while OPF, switch grass, cereal straw and corn stalk all have approximately 18 MJ per kilogram of energy content. Vine shoot is only slightly lower at $17 \mathrm{MJ} / \mathrm{kg}$.

Moisture content, i.e. the amount of water in biomass is one the parameters that affects the performance of a gasification system. In gasification, the moisture content is normally quantified as a percentage. A number of studies have been performed to analyze the effect of moisture content in OPF on the producer gas composition and heating value. A simulation model carried out by Atnaw et al. [5] predicted the heating value (calorific value) of syngas produced from OPF by gasification. The results showed that the heating value decreases with an increase in moisture content and for a moisture content of 15 percent, the heating value of the gas is only between 4 and $5 \mathrm{MJ} / \mathrm{m}^{3}$. In experiments conducted by Guangul et al.[6], the concentrations of carbon monoxide, $\mathrm{CO}$, methane, $\mathrm{CH}_{4}$ and hydrogen gas, $\mathrm{H}_{2}$ in producer gas obtained by gasification were all reduced by an increase in the moisture content of feedstock OPF from 10 percent to 20 percent. The study conducted by Sulaiman et al. [7] confirms the work conducted in [5] and [6]. The performance of the gasifier drops due to a rising percentage of moisture content in the feedstock.

Another important parameter is the air fuel ratio. This is the ratio of mass of air that enters the gasifier to the mass of biomass fed in, in order to obtain a conversion of carbonaceous material into gaseous product. The simulation of OPF gasification done by Atnaw et al. [2] showed that the mass fractions of combustible gases, $\mathrm{CO}$ and $\mathrm{CH}_{4}$, are greater at lower air fuel ratio. The simulation also showed a slight increase in the carbon dioxide, $\mathrm{CO}_{2}$ mass fraction when the air fuel ratio was raised from 5 percent to 80 percent. In terms of calorific value, the variation of the air fuel ratio between 1.6 and 2.5 from [5] led to decreasing calorific value from approximately $4.7 \mathrm{MJ} / \mathrm{m}^{3}$ to $2.6 \mathrm{MJ} / \mathrm{m}^{3}$. Another study by Atnaw et al. [8] found that the optimum air fuel ratio is 0.37 , and this value was able to produce gas with calorific value of $4.8 \mathrm{MJ} / \mathrm{Nm}^{3}$. The calorific value initially increased as the ratio increase from 0.27 to 0.37 , but then decreased as the ratio continued to increase from 0.37 to 0.59 .

Several studies have been done to model the downdraft gasification of various feed stocks such as coconut husks and date palm waste. Studies in [5] and [9] used ASPEN PLUS software to model the downdraft gasification system. This software has its own built in reactors that can be used to simulate the drying zone, the pyrolysis zone, the oxidation zone and the reduction zone of the downdraft gasifier. Both studies considered heat as well as mass transfer in the model. Furthermore, the chemical and physical properties of the feedstock were defined using a special property method embedded in the software itself. Another study by Mohamad Isa [10] modelled the downdraft gasification using MATLAB SIMULINK software. The model was based on a calculation of the numbers of moles and took into consideration various chemical reactions that occur in the gasifier.

Therefore, in this research, a downdraft gasifier was chosen for the modelling of a gasification system. The system was designed according to the chemical reactions that take place in each of the four zones of the gasifier with calculations on a mass flow basis. MATLAB SIMULINK was used to model and simulate the OPF gasification system. To ease the understanding, the chemical reactions occurring in each zone are balanced using "kilogram" terms, which eliminate the use of typical "mass" equations. Hence, modeling can be done more easily and the process is easier to understand, in particular for people who are not familiar with chemical equations and chemical processes. Finally, the input to the system was defined in terms of a generic chemical formula, $\mathrm{CH}_{\mathrm{x}} \mathrm{O}_{\mathrm{y}}$ and the system considered mass transfer only.

\section{$2 \quad$ Methodology}

The OPF downdraft gasification system model consists of seven sub models as shown in the block diagram of Figure 1. The model follows the arrangement of zones in a downdraft gasifier [11]. The first output from the model is syngas composition which is obtained from the mass fraction sub model. The second output from the model is the syngas calorific value that is determined in the mole fraction sub model. Lastly, the third output is the syngas energy which is obtained from the syngas energy sub model. 


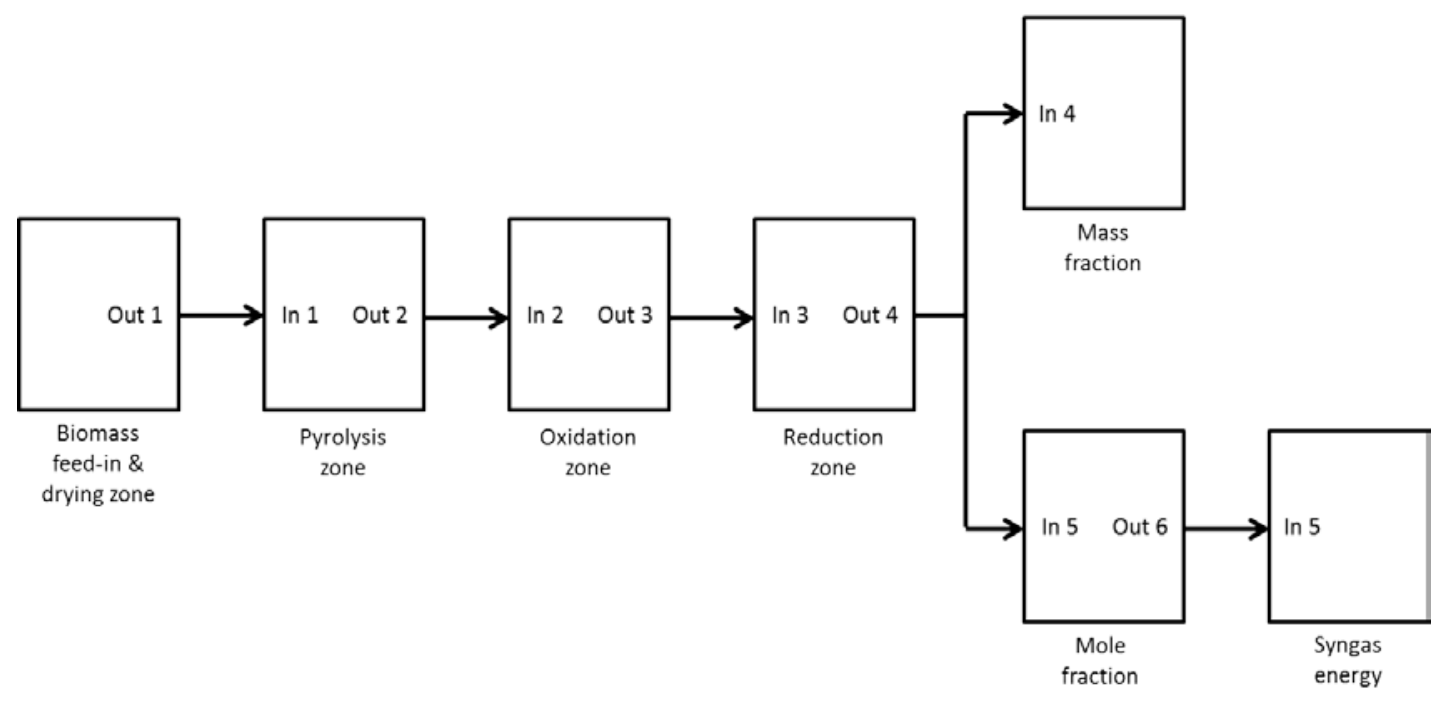

Figure 1. Block diagram of the downdraft gasification model.

\subsection{Drying Zone Sub Model}

The main function of this sub model is to obtain the mass of $\mathrm{C}, \mathrm{H}$ and $\mathrm{O}$ in the dry OPF and the mass of $\mathrm{H}$ and $\mathrm{O}$ in the moisture content based on $1 \mathrm{~kg}$ of $\mathrm{OPF}$. In order to do this, empirical formula of OPF must be calculated by using ultimate analysis data. This data is obtained from [4] due to limitations of equipment to perform a new ultimate analysis of biomass. The moisture content in each $1 \mathrm{~kg}$ of OPF is varied from 5 percent up to 20 percent in step five with constant air fuel ratio set to 0.26 . If the moisture content percentage is known, the mass of dry OPF and mass of moisture can be calculated using equation (1) and equation (2) respectively. The molecular mass of OPF and the molecular mass of moisture content, $\mathrm{H}_{2} \mathrm{O}$ can be calculated using equation (3). Hence, the mass of $\mathrm{C}, \mathrm{H}$ and $\mathrm{O}$ in the dry $\mathrm{OPF}$ and moisture content can be found by using equation (4). The masses of $\mathrm{C}, \mathrm{H}$ and $\mathrm{O}$ in both dry OPF and with moisture are summed up using equation (5), (6) and (7) respectively, and become the output to this sub model.

$$
\begin{gathered}
\text { Mass of dry } \operatorname{OPF}(\mathrm{g})=1000 \mathrm{~g}-(\mathrm{MC} \%)(1000 \mathrm{~g}) \\
\text { Mass of moisture }(\mathrm{g})=(\mathrm{MC} \%)(1000 \mathrm{~g})
\end{gathered}
$$

Molecular mass $(\mathrm{g} / \mathrm{mol})=\sum_{\text {Element }=1}^{3}($ Atomic mass of Element $\mathrm{g} / \mathrm{mol})\left(\text { Element }_{\mathrm{n}} \text { Empirical formula }\right)^{2}$ where

$$
\begin{aligned}
& \text { Element }_{1}=\text { Carbon } \\
& \text { Element }_{2}=\text { Hydrogen } \\
& \text { Element }_{3}=\text { Oxygen }
\end{aligned}
$$

Mass of Element $(\mathrm{g})$

$$
\begin{gathered}
=\frac{\text { Atomic mass of Element }(\mathrm{g} / \mathrm{mol})}{\text { Molecular mass of OPF }(\mathrm{g} / \mathrm{mol})} \times[\text { Mass of dry OPF }(\mathrm{g}) \text { OR Mass of moisture }(\mathrm{g})] \\
\text { Total } \mathrm{C}=\mathrm{C}_{\text {dry feedstock }} \\
\text { Total H }=\mathrm{H}_{\text {dry feedstock }}+\mathrm{H}_{\text {moisture content }} \\
\text { Total } \mathrm{O}=\mathrm{O}_{\text {dry feedstock }}+\mathrm{O}_{\text {moisture content }}
\end{gathered}
$$




\subsection{Pyrolysis Zone Sub Model}

The drying zone in a downdraft gasifier removes volatile substances from the OPF by vaporization at high temperature. Its model is developed by using the chemical reactions that take place in the pyrolysis zone. They are generated based on the study in [2] and can be seen in equations (8) to (12). In each case, the chemical reactions that occur in the zone are balanced by inspection and the mass of each component in each equation must be found using both equation (13) and (14).

$$
\begin{gathered}
\mathrm{O}_{2}+2 \mathrm{H}_{2} \rightarrow 2 \mathrm{H}_{2} \mathrm{O} \\
\mathrm{O}_{2}+\mathrm{C} \rightarrow \mathrm{CO}_{2} \\
\mathrm{O}_{2}+2 \mathrm{C} \rightarrow 2 \mathrm{CO} \\
2 \mathrm{H}_{2}+\mathrm{C} \rightarrow \mathrm{CH}_{4} \\
\mathrm{H}_{2}+2 \mathrm{C} \rightarrow \mathrm{C}_{2} \mathrm{H}_{2}
\end{gathered}
$$

New Number of Mole $(\mathrm{mol})$

$$
=\frac{\text { Mass of Element }(\mathrm{g})}{(\text { Empiral Number of Element })\left(\text { Atomic mass of Element } \frac{\mathrm{g}}{\mathrm{mol}}\right)}
$$

Mass of Element $(\mathrm{g})$

$=$ New Number of Mole $(\mathrm{mol}) \times$ Empirica Number of Element $\times$ Atomic Mass of Element $\mathrm{g} / \mathrm{mol}$

The use of equations (13) and (14) is repeated in the remaining balanced chemical equations of this gasification model.

\subsection{Oxidation Zone Sub Model}

The oxidation zone provides heat to other zones and at the same time breaks down other chemical components of OPF. The chemical reactions that take place in this sub model are generated from the studies in [2], [10], [12] and can be observed below. These equations are balanced and the mass of each component are determined using equations (13) and (14).

$$
\begin{aligned}
2 \mathrm{H}_{2}+\mathrm{O}_{2} & \rightarrow 2 \mathrm{H}_{2} \mathrm{O} \\
2 \mathrm{C}_{2} \mathrm{H}_{2} & +5 \mathrm{O}_{2} \\
\mathrm{CH}_{4}+\frac{3}{2} \mathrm{O}_{2} & \rightarrow \mathrm{CO}+2 \mathrm{CO}_{2}+2 \mathrm{H}_{2} \mathrm{O} \\
\mathrm{O}_{2}+\mathrm{C} & \rightarrow \mathrm{CO}_{2} \\
\mathrm{O}_{2}+2 \mathrm{C} & \rightarrow 2 \mathrm{CO}
\end{aligned}
$$

The air fuel ratio (AFR) is also varied in this sub model to see its effect on the syngas composition, calorific value and energy. The AFR is varied from 0.26 to 0.6. In addition, as the AFR is varied, the OPF moisture content is set to the least value which is 5 percent. The air entering this zone is determined through equation (20) obtained from [10]. Since this equation gives the amount of $\mathrm{O}_{2}$ in terms of mole, this value must be converted to mass using equation (14).

$$
\mathrm{a}(\mathrm{mol})=\left(\mathrm{C}_{\text {mole }}+\frac{\mathrm{H}_{\text {mole }}}{4}-\frac{\mathrm{O}_{\text {mole }}}{2}\right)()
$$

where $\quad \mathrm{a}=$ Mole of oxygen from external air

$\mathrm{C}_{\mathrm{m}}=$ Mole of carbon from drying zone

$\mathrm{H}_{\mathrm{mc}}=$ Mole of hydrogen from drying zone

$\mathrm{O}_{\mathrm{mc}}=$ Mole of oxygen from drying zone

$=$ Air fuel ratio 


\subsection{Reduction Zone Sub Model}

This sub model has four main chemical reactions that take place in the absence of $\mathrm{O}_{2}$. The chemical equations of these reactions are the Boudouard reaction, the water gas reaction, methanation and steam reforming, referred from [11] and can be observed respectively in equations (21), (22), (23) and (24). Only the first three subsystems are fed with remaining $\mathrm{C}$ from oxidation zone since the chemical reactions that take place involve the unburned $\mathrm{C}$. These equations are balanced and the masses of each component are determined using equations (13) and (14).

$$
\begin{gathered}
\mathrm{C}+\mathrm{CO}_{2} \rightarrow 2 \mathrm{CO} \\
\mathrm{C}+\mathrm{H}_{2} \mathrm{O} \rightarrow \mathrm{CO}+\mathrm{H}_{2} \\
2 \mathrm{H}_{2}+\mathrm{C} \rightarrow \mathrm{CH}_{4} \\
\mathrm{CH}_{4}+\mathrm{H}_{2} \mathrm{O} \rightarrow 3 \mathrm{H}_{2}+\mathrm{CO}
\end{gathered}
$$

The outputs of the reduction zone sub model are the masses of $\mathrm{CO}, \mathrm{CO}_{2}, \mathrm{H}_{2}, \mathrm{CH}_{4}$ and $\mathrm{H}_{2} \mathrm{O}$. The final amount of these gases is calculated by using equations (25), (26), (27), (28) and (29) respectively.

Total $\mathrm{CO}=\mathrm{CO}$ from oxidation $+\mathrm{CO}$ from Boudouard reaction

$+\mathrm{CO}$ from water gas reaction $+\mathrm{CO}$ from steam reforming

Total $\mathrm{CO}_{2}=\mathrm{CO}_{2}$ from oxidation $-\mathrm{CO}_{2}$ from Boudouard reaction

Total $\mathrm{H}_{2}=\mathrm{H}_{2}$ from water gas reaction $+\mathrm{H}_{2}$ from steam reforming $-\mathrm{H}_{2}$ from methanation

Total $\mathrm{CH}_{4}=\mathrm{CH}_{4}$ from methanation $-\mathrm{CH}_{4}$ from steam reforming

Total $\mathrm{H}_{2} \mathrm{O}=\mathrm{H}_{2} \mathrm{O}$ from oxidation $-\mathrm{H}_{2} \mathrm{O}$ from water gas $-\mathrm{H}_{2} \mathrm{O}$ from steam reforming

\subsection{Mass fraction Sub Model}

The composition of the syngas from gasification of OPF is found by calculating the mass fraction of the gasses produced in the reduction zone. Initially, the total mass of the gasses must be calculated by adding up the mass of each gas. This is described in equation (30). Then, the mass fraction of each gas is determined by dividing the mass of each gas by the total gas mass using equation (31).

$$
\begin{gathered}
\text { Total mass }(\text { gram })=\text { Mass of }\left(\mathrm{CO}+\mathrm{H}_{2}+\mathrm{H}_{2} \mathrm{O}+\mathrm{CO}_{2}+\mathrm{CH}_{4}\right) \\
\text { Mass fraction }=\frac{\text { Mass of each gas }(\text { gram })}{\text { Total mass }(\text { gram })}
\end{gathered}
$$

\subsection{Mole Fraction Sub Model}

In order to determine the calorific value of the syngas, the mole fraction of each gas must be obtained first. This is initially done by converting the mass of each gas produced in reduction zone into mole by following equation (32). Then, the total number of mole must be calculated by adding up mole of each gas using equation (33). And lastly, the mole fraction of each gas can be found by using equation (34).

$$
\begin{gathered}
\text { Mole of each gas }(\mathrm{mol})=\frac{\text { Mass of gas }(\text { gram })}{\text { Molecular mass of gas }(\text { gram } / \mathrm{mol})} \\
\text { Total mole }(\mathrm{mol})=\mathrm{Mol} \text { of }\left(\mathrm{CO}+\mathrm{H}_{2}+\mathrm{H}_{2} \mathrm{O}+\mathrm{CO}_{2}+\mathrm{CH}_{4}\right) \\
\text { Mole fraction }=\frac{\text { Mole of each gas }(\text { mole })}{\text { Total mole }(\text { mole })}
\end{gathered}
$$

$\mathrm{H}_{2}$, $\mathrm{CO}$, and $\mathrm{CH}_{4}$ are the three important gasses in determining the calorific value of syngas because they are the combustible gases produced from the gasification of OPF. The calorific value is determined by using equation (35) from [13] where it involves the combustible gases and their corresponding heating value from [14]. 


$$
\begin{aligned}
\text { Calorific value }\left(\mathrm{MJ} / \mathrm{m}^{3}\right) & =(\mathrm{CO} \text { mole fraction })\left(12.63 \mathrm{MJ} / \mathrm{m}^{3}\right) \\
& +\left(\mathrm{H}_{2} \text { mole fraction }\right)\left(12.76 \mathrm{MJ} / \mathrm{m}^{3}\right) \\
& +\left(\mathrm{CH}_{4} \text { mole fraction }\right)\left(39.76 \mathrm{MJ} / \mathrm{m}^{3}\right)
\end{aligned}
$$

\subsection{Syngas Energy Sub Model}

The output of this sub model, syngas energy is obtained by dividing the calorific value of the syngas from previous section by $3.6 \mathrm{MJ} / \mathrm{kWh}$ as shown in equation (36) below.

$$
\text { Energy }\left(\mathrm{kWh} / \mathrm{m}^{3}\right)=\frac{\text { Syngas calorific value }\left(\mathrm{MJ} / \mathrm{m}^{3}\right)}{3.6(\mathrm{MJ} / \mathrm{kWh})}
$$

where $1 \mathrm{kWh}=3.6 \mathrm{MJ}$

\section{$3 \quad$ Results and Discussions}

The analysis of the effect of OPF moisture content and air fuel ratio is categorized into three parts which are syngas composition, syngas calorific value and syngas energy.

\subsection{Effect of OPF Moisture Content on the Syngas Composition}

The syngas consists of mainly $\mathrm{H}_{2} \mathrm{O}, \mathrm{H}_{2}, \mathrm{CO}, \mathrm{CO}_{2}$, and $\mathrm{CH}_{4}$ where the proportion of each of these elements was calculated based on mass fraction. The results are illustrated in Figure 2. The figure shows that the fractions of the combustible gases, $\mathrm{CO}, \mathrm{H}_{2}$, and $\mathrm{CH}_{4}$ decrease with increasing OPF moisture content. Their trends are approximately the same as produced from ASPEN PLUS software obtained in [9]. However, the syngas composition obtained from this work is different in terms of value range compared to the previous study stated due to different parameters in the software used. The figure also shows that the composition of $\mathrm{CO}_{2}$ in the syngas increases when the moisture content is increased. This is because an increment of OPF moisture content causes the gasifier to react by producing more heat to remove the moisture [15]. The reaction eventually causes more burning of carbon from the feedstock due to this high heat. Furthermore, the formation of $\mathrm{H}_{2} \mathrm{O}$ was more favourable in the gasifier as the moisture content increased, leading to decreased production of $\mathrm{H}_{2}$ and $\mathrm{CH}_{4}$.

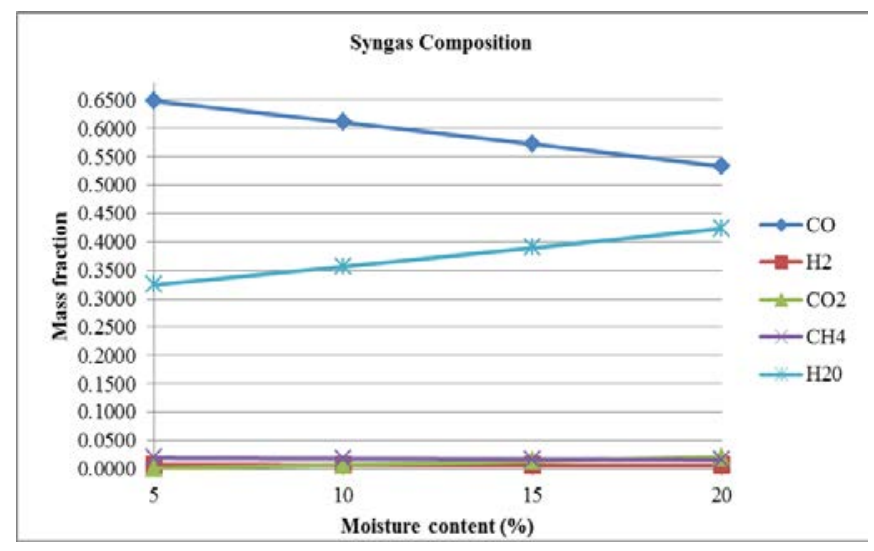

Figure 2. Syngas composition with variation in OPF moisture content.

\subsection{Effect of OPF Moisture Content on the Syngas Calorific Value}

The compositions of combustible gases which are $\mathrm{CO}, \mathrm{H}_{2}$, and $\mathrm{CH}_{4}$ in the syngas are the most important. 
Their amounts determine the calorific value of the syngas. The variation of syngas calorific value with OPF moisture content is illustrated in Figure 3.

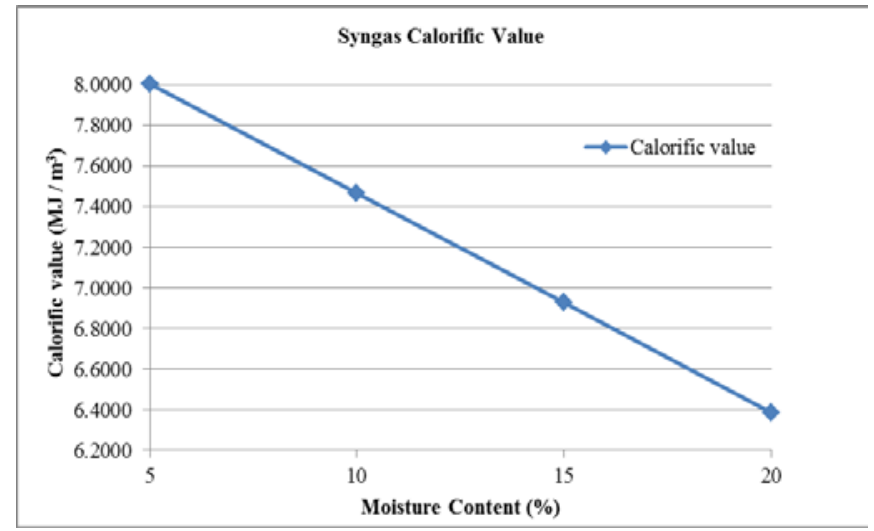

Figure 3. Syngas calorific value at different OPF moisture content.

The reduction in fractions of combustible gases causes the calorific value of the syngas to reduce from $8.005 \mathrm{MJ} / \mathrm{m}^{3}$ to $6.387 \mathrm{MJ} / \mathrm{m}^{3}$ as the moisture is increased from 5 percent up to 20 percent. The trend generated in Figure 3 is similar to the calorific value trend generated using ASPEN PLUS from [5].

\subsection{Effect of OPF Moisture Content on the Syngas Energy}

The calorific value obtained is further converted to energy so that the effect of moisture content on the syngas energy can be observed. The resulting energy is depicted in Figure 4.

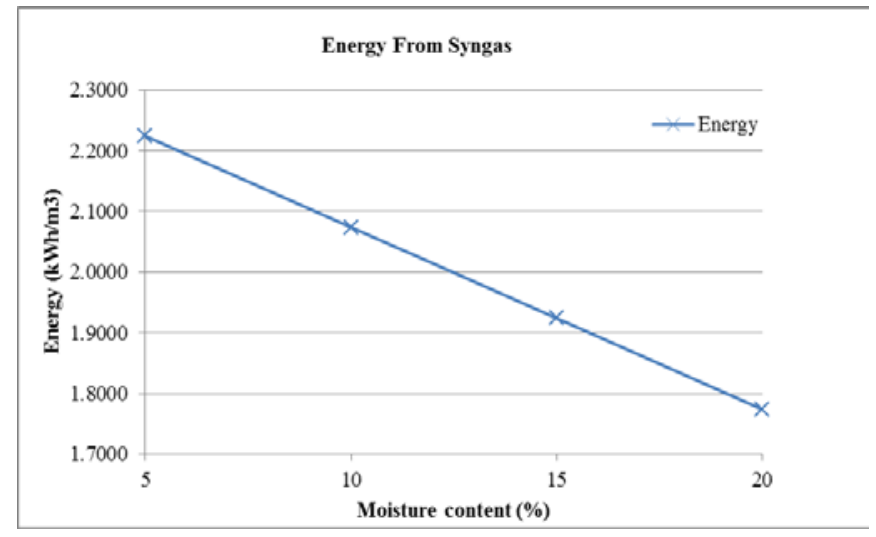

Figure 4. Energy from syngas at different OPF moisture content.

Figure 4 shows that the energy from syngas decreases linearly as the moisture content of OPF is raised from 5 percent to 20 percent. The energy reduces from $2.224 \mathrm{kWh} / \mathrm{m}^{3}$ at 5 percent to 1.774 $\mathrm{kWh} / \mathrm{m}^{3}$ at 20 percent.

\subsection{Effect of Air Fuel Ratio on the Syngas Composition}

As the equivalence air fuel ratio was set to 0.25 , the fraction of $\mathrm{CO}_{2}$ in the syngas resulted in negative value, -0.01140 mass fraction which is impossible. Therefore, the starting air fuel ratio was set to 0.26 , where the fractions of all the gases have positive values. Also, as the equivalence air fuel ratio was set to 0.61, the fractions of $\mathrm{H}_{2}$ and $\mathrm{CH}_{4}$ resulted in negative values of -0.000013 and -0.00003 mass fractions respectively. Similarly to the previous condition of $\mathrm{CO}_{2}$, these values are impossible. Therefore, the final 
air fuel ratio was set to 0.6 with the reason that this gasification system can at least generate small amount of $\mathrm{H}_{2}$ and $\mathrm{CH}_{4}$.

Figure 5 illustrates the trends of the syngas composition produced from Simulink. The trends here are similar to the trends obtained from ASPEN PLUS in [9]. Figure 5 shows that the compositions of combustible gases, $\mathrm{CO}, \mathrm{H}_{2}$, and $\mathrm{CH}_{4}$ are larger when the air fuel ratio is small.

Figure 5 also shows that the portion of each combustible gas is reducing as the air fuel ratio is increased.

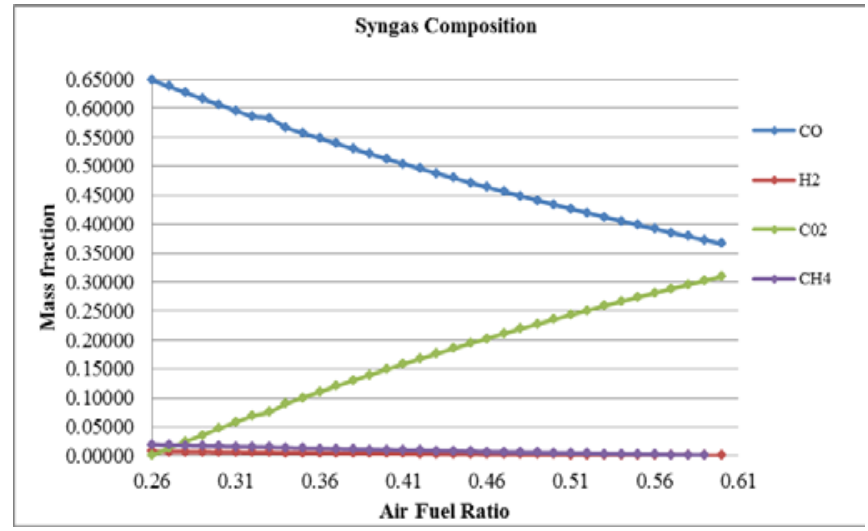

Figure 5. Syngas composition with variation in air fuel ratio.

Also note that the feedstock tends to burn more completely when as air fuel ratio increases, as shown by the increasing fraction of $\mathrm{CO}_{2}$ in Figure 5. Similar trends in [9] prove that the model developed in this research project is consistent with the ones simulated in ASPEN PLUS.

\subsection{Effect of Air Fuel Ratio on the Syngas Calorific Value}

Figure 6 shows a decreasing trend of calorific value from $8.132 \mathrm{MJ} / \mathrm{m}^{3}$ at an air fuel ratio of 0.26 to $4.137 \mathrm{MJ} / \mathrm{m}^{3}$ at an air fuel ratio of 0.6. Again, this is due to a reduction in the amount of combustible gases. The trend obtained from Simulink here is similar to that in [5].

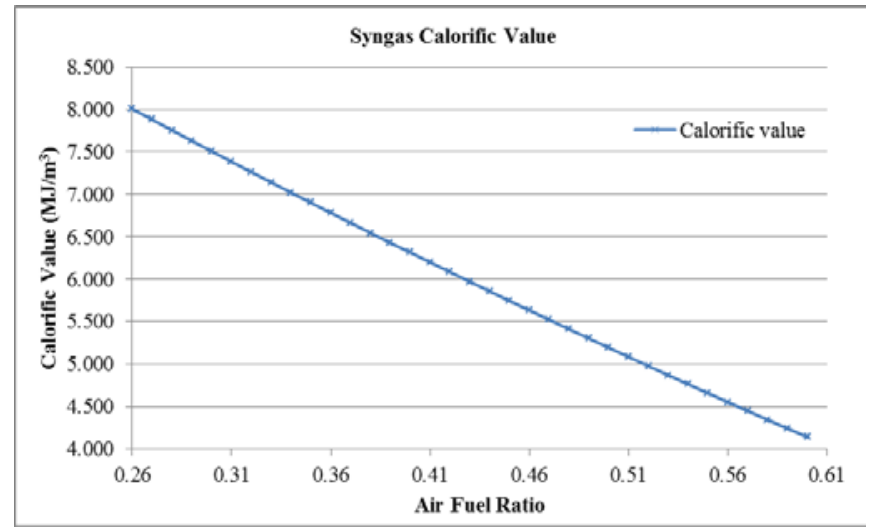

Figure 6. Syngas calorific value at different air fuel ratio.

\subsection{Effect of Air Fuel Ratio on the Syngas Energy}

Figure 7 shows that the energy in syngas reduces $2.259 \mathrm{kWh} / \mathrm{m}^{3}$ at an equivalence air fuel ratio of 0.26 to $1.149 \mathrm{kWh} / \mathrm{m}^{3}$ at an equivalence air fuel ratio of 0.6 . 


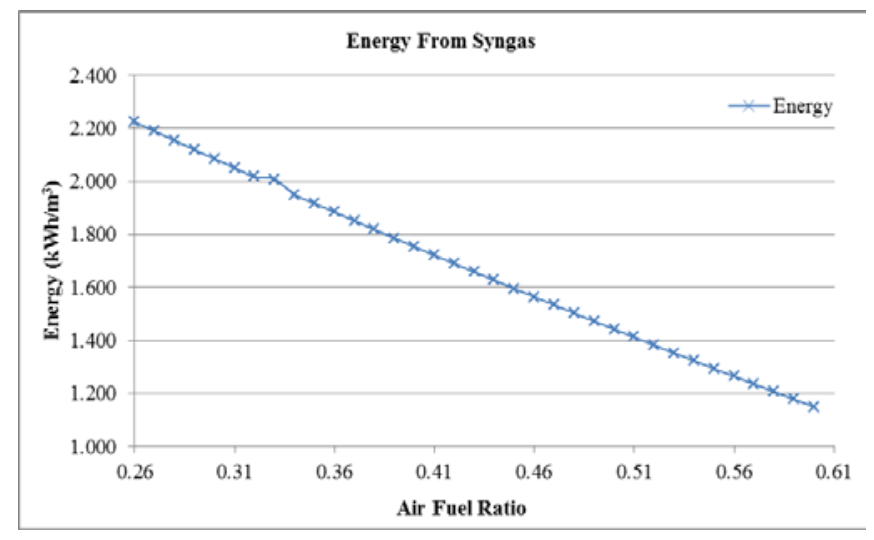

Figure 7. Energy from syngas at different air fuel ratio.

\section{Conclusion}

The gasification of oil-palm fronds model was based on a downdraft gasifier. The model was designed to have seven sub models, each containing subsystems to provide convenience in constructing the model in Matlab/Simulink. Four of the sub models represent four zones in the downdraft gasifier. The simulation of the gasification model produces results in terms of syngas composition, syngas calorific value and energy. The effects of OPF moisture content and air fuel ratio on these outputs were identified. Through the simulation, it was found that increasing OPF moisture content and increasing air fuel ratio each resulted in a decreased production of combustible gases. This, consequently, led to lower syngas calorific value and lower syngas energy. The results generated are consistent with previous researches in terms of trends (when using other biomass materials). Despite the low production of $\mathrm{CH}_{4}$ and $\mathrm{H}_{2}$, the use of oilpalm fronds as feedstock to the gasification system led to high production of CO. This shows that OPF has a good potential as a source of energy. The proposed 'kilogram' balance equation enabled the chemical reactions that occur in each zone to be modelled more easily and the whole process to be understood more easily. In future work, energy calculation will be extended to be presented as energy per $\mathrm{kg}$ of dry biomass and composition of syngas will be presented as molar fractions of gases.

Acknowledgement. The authors would like to thank RMC, POWER Dept., FKE and CEES, Universiti Teknologi Malaysia and the Ministry of Higher Education of Malaysia for the financial support provided under RUG (12H00) and FRGS (4F794) to carry out this research.

\section{References}

1. M. Z. Jaafar, W. H. Kheng, and N. Kamaruddin, "Greener energy solutions for a sustainable future: Issues and challenges for Malaysia," Energy Policy, vol. 31, no. 11, pp. 1061-1072, 2003.

2. S. M. Atnaw and S. A. Sulaiman, "Modeling and simulation study of downdraft gasifier using oil-palm fronds," in ICEE 2009 - Proceeding 2009 3rd International Conference on Energy and Environment: Advancement Towards Global Sustainability, 2009, pp. 284-289.

3. Energy Commission, "Renewable Energy Power Plant Project in Malaysia," 2014.

4. S. M. Atnaw, S. A. Sulaiman, and S. Yusup, "Downdraft gasification of oil palm fronds," Trends Appl. Sci. Res., vol. 6, no. 9, pp. 1006-1018, 2011.

5. S. M. Atnaw, S. A. Sulaiman, and S. Yusup, "Prediction of calorific value of syngas produced from oil-palm fronds gasification," in 2011 National Postgraduate Conference - Energy and Sustainability: Exploring the Innovative Minds, 2011, pp. 2-5.

6. F. M. Guangul, S. A. Sulaiman, and A. Ramli, "Study of the effects of operating factors on the resulting producer gas of oil palm fronds gasification with a single throat downdraft gasifier," Renew. Energy, vol. 72, pp. $271-283,2014$. 
7. S. A. Sulaiman, S. M. Atnaw, and M. N. Z. Moni, "Experimental Study on Temperature Profile of Fixed - Bed Gasification of Oil-Palm Fronds," Int. J. Technol., vol. 3, no. 1, pp. 35-44, 2012.

8. S. M. Atnaw, S. A. Sulaiman, and S. Yusup, "Syngas production from downdraft gasification of oil palm fronds," Energy, vol. 61, pp. 491-501, 2013.

9. S. M. Atnaw, S. A. Sulaiman, and S. Yusup, "A Simulation Study of Downdraft Gasification of Oil-Palm Fronds using ASPEN PLUS," J. Appl. Sci., vol. 11, no. 11, pp. 1913-1920, 2011.

10. M. T. Mohamad Isa, "Electrical Energy Generation Of Biomass Gasification System Using Coconut Husks," Universiti Teknologi Malaysia, 2016.

11. C. Dejtrakulwong and S. Patumsawad, "Four Zones Modeling of the Downdraft Biomass Gasification Process: Effects of Moisture Content and Air to Fuel Ratio," Energy Procedia, vol. 52, pp. 142-149, 2014.

12. R. Elneel, S. Anwar, and B. Ariwahjoedi, "Prediction of heating values of oil palm fronds from ultimate analysis," J. Appl. Sci., vol. 13, no. 3, pp. 491-496, 2013.

13.A. Melgar, J. F. Perez, H. Laget, and A. Horillo, "Thermochemical equilibrium modelling of a gasifying process," Energy Convers. Manag., vol. 48, no. 1, pp. 59-67, 2007.

14. T. Waldheim, L. Nilsson, "Heating value of gases from biomass gasification," 2001.

15. S. Pandey, B. Baral, S. Karki, and A. Upreti, "Prediction of Syngas Composition from Biomass Gasification using Thermodynamics Equilibrium Model," Rentech Symp. Compend., pp. 5-8, 2013 